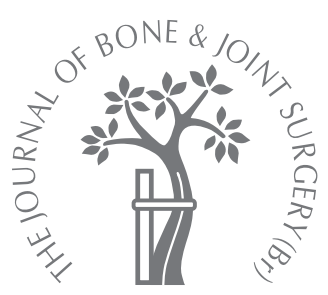

S. E. Gwilym, T. C. B. Pollard, A. J. Carr

From the Nuffield Orthopaedic Centre, Oxford, England
- S. E. Gwilym, BSc(Hons), MRCS, ARC Clinical Research Fellow \& Girdlestone Memoria Scholar

T. C. B. Pollard, BSc(Hons), MRCS, Specialist Registrar \& Botnar Surgical Research Fellow

A. J. Carr, ChM, FRCS, Nuffield Professor of Orthopaedic Surgery Nuffield Department of Orthopaedic Surgery University of Oxford, Nuffield Orthopaedic Centre, Windmil Road, Headington, Oxford OX3 7LD, UK.

Correspondence should be sent to Mr S. E. Gwilym; e-mail: s_gwilym@doctors.org.uk

(C2008 British Editorial Society of Bone and Joint Surgery doi:10.1302/0301-620X.90B3 $20167 \$ 2.00$

$J$ Bone Joint Surg $[\mathrm{Br}]$ 2008;90-B:280-7.

- ANNOTATION

\title{
Understanding pain in osteoarthritis
}

The majority of patients with osteoarthritis present to orthopaedic surgeons seeking relief of pain and associated restoration of function. Although our understanding of the physiology of pain has improved greatly over the last 25 years there remain a number of unexplained pain-related observations in patients with osteoarthritis. The understanding of pain in osteoarthritis, its modulation and treatment is central to orthopaedic clinical practice and in this annotation we explore some of the current concepts applicable. We also introduce the concept of the 'phantom joint' as a cause for persistent pain after joint replacement.

The majority of patients who present to orthopaedic surgeons do so with pain and loss of function. Musculoskeletal pain is the primary cause of chronic pain worldwide. ${ }^{1}$ Commonly, it is the perception of pain which troubles the patient and is the principle reason for seeking redress. ${ }^{2}$ Despite scientific advances in both its understanding and treatment, the burden of musculoskeletal pain is estimated to have increased between two- and fivefold over the last 40 years. $^{3}$

During this period, research in pain has led to an improved understanding of nociceptive transmission ${ }^{4}$ and how a stimulus is modified as it passes from peripheral detection, to awareness and to behaviour. It is now apparent that the process is rather more complex than the initial theory proposed by Descartes in the 17 th century, in which pain sensation was thought to pass, unadulterated, from stimulus to brain (Fig. 1). ${ }^{5}$

From a research perspective, pain associated with osteoarthritis (OA) presents a number of dilemmas that demand further consideration. First, not all OA causes pain and it is not possible to predict with any degree of precision who will experience pain in the presence of joint degeneration. Secondly, the pain associated with OA has been shown to be reduced using techniques of placebo surgery ${ }^{6,7}$, implying that not all the benefit seen following operations can be attributed to the technical process alone. Finally, more than one in ten patients who undergo joint replacement continue to experience pain attributed to the affected joint. ${ }^{8,9}$

In 1952, Kellgren and Lawrence ${ }^{10}$ quantified the relationship between radiologically- identified $\mathrm{OA}$ and pain in a cohort of coal miners. Only $24 \%$ of those with radiologically demonstrable OA of the knee had pain and $8 \%$ of 'normal' knees were painful. This poor correlation between radiologically determined $\mathrm{OA}$ and pain has subsequently been highlighted by a number of other authors, ${ }^{11-16}$ one of whom concluded that the epidemiology of OA and the epidemiology of pain in the knee have something, but not much, in common. ${ }^{16}$

The reason for this poor correlation is multifactorial, involving the sensitivity of radiographs to quantify the disease, the heterogeneity of the disease process and an individual's interpretation and behaviour towards a potentially painful stimulus. This variation in response to pain has historically been perceived by clinicians as a nuisance, and difficult to assess and quantify. ${ }^{17}$

In this annotation, we aim to consider the pathway of transmission of pain, the role of psychosocial factors in the perception of pain and the mechanism of action of the various methods of control of pain employed in arthritis.

\section{Clinical presentation of osteoarthritis}

The localised, unilateral pain experienced in patients with OA affecting a single joint is well recognised. More detailed assessments have revealed that joint-specific localisation may be an oversimplification of the clinical picture, as patients with OA of the hip have quantifiable changes in pain perception and skin sensitivity at distant ipsilateral and contralateral sites. ${ }^{18}$ Despite this broader morbidity of disorders of the joint, surgical treatment isolated to the joint appears to remove pain at these secondary pain 


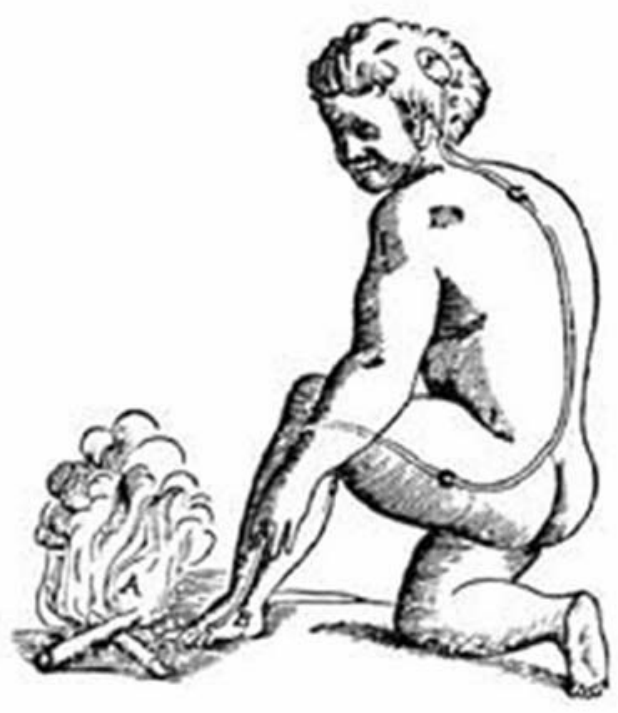

Fig. 1

The model proposed by Descartes of pain transmission ${ }^{5}$ showing a single pathway from stimulus to awareness.

sites in addition to the localised joint pain. ${ }^{18}$ This suggests that operation has a secondary influence at a central level to produce these distant effects.

\section{Pain mechanisms in the osteoarthritic joint}

There are two related but different terms which define pain: nociception and pain. Nociception is a neurophysiological term and describes the activity in a nerve pathway which transmit signals from a potentially noxious stimulus but is not always perceived as painful. The term pain is used to describe the subjective experience that accompanies nociception, but can also arise without a stimulus and includes the cognitive and emotional response.

\section{Detection of peripheral pain}

Arthritic pain is the final interpretation of a noxious stimulus within the joint. The innervation of a typical diarthroidal joint offers a number of potential sources for this initial neuronal input. Orthopaedic enquiry into which elements of the synovial joint are responsible for pain dates back to the 19 th century. ${ }^{19}$

Nociceptors and the spinal cord. A $\delta$ fibres and $C$ fibres form the afferent limb of the pain reflex arc and together are responsible for detecting noxious stimuli which damage or threaten the body's integrity, and are therefore termed 'nociceptors'. ${ }^{20,21}$ A $\delta$ fibres initiate the sharp pain associated with acute injury while $\mathrm{C}$ fibres are responsible for the less well-defined aching pain. The free-ending receptors of this type of nerve may have different sensitivities to chemi-

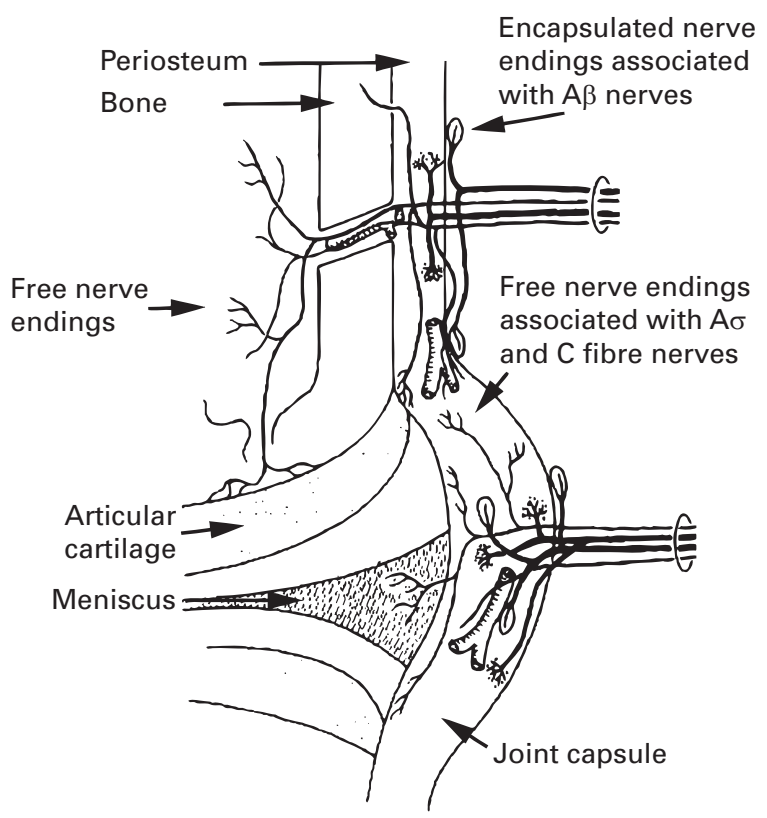

Fig. 2

Diagram showing the neural transmission within the human knee joint. Adapted from Zimmerman. ${ }^{25}$

cal, mechanical and thermal stimuli. ${ }^{22-24}$ Nociceptor fibres form a plexus which invades the periosteum as well as innervating subchondral bone, joint capsule and fibrocartilagenous structures (Fig. 2). ${ }^{25}$

Following initiation of nociceptor activity, the first point of integration and modulation of the afferent signal is at the nociceptor synapse of the dorsal horn neurone of the spinal cord. Nociceptor impulses of a sufficient intensity and frequency will produce post-synaptic depolarisation in the spinal neurones.

From the dorsal synapse, either directly or via an interneurone, the nociceptive impulse is transmitted towards the supra-spinal structures via one of four spinal tracts: the contralateral spinothalamic tract, which terminates in the numerous nuclei of the thalamus; the spinoreticular and spinomesencephalic tracts, which transmit to the medulla and brainstem; or the spinohypothalamic tract, which terminates in the hypothalamus (Fig. 3). ${ }^{26}$

The anatomy of the supraspinal pain matrix. The term 'pain matrix' is used to encompass a number of discoveries and ambiguities in our knowledge of how the supraspinal structures (brain stem, cerebellum, cerebral cortex and cerebral sub-cortical areas) process a nociceptive input. The term matrix offers suitable latitude to account for this constantly developing science and has two inherent foundations. First, that there are numerous regions involved, and secondly that the interpretation of a nociceptive impulse involves neuronal interaction through connections both in parallel and in series. 


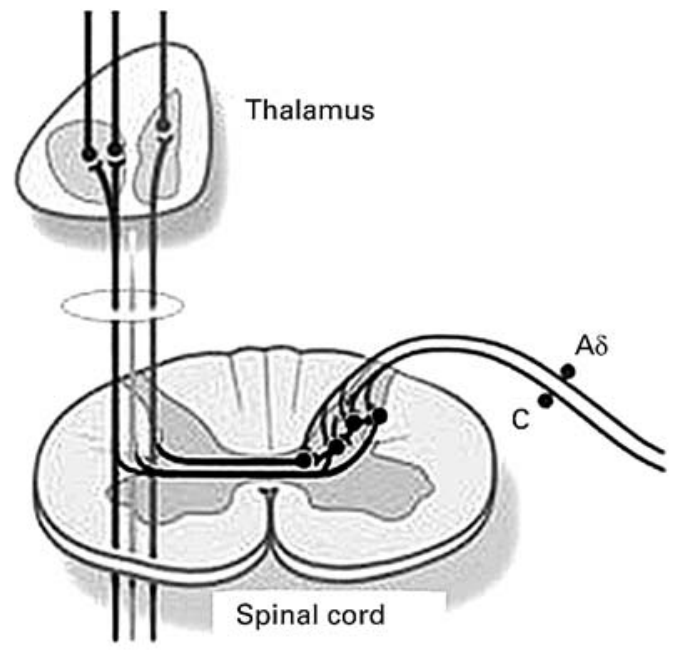

Fig. 3

Typical spinal pathways involved in transmission from the periphery to the brain.

Imaging modalities such as positive emission tomography and functional MRI have been used to determine the activity of cortical and sub-cortical areas during application of painful stimuli. These techniques detect focal changes in blood flow within the brain following peripheral stimulation and produce a map of brain activity. A detailed account for the use of these techniques is beyond the scope of this annotation but may be found elsewhere. $^{27,28}$

Correlating the areas of the brain which are active during the perception of pain and those active during unrelated cognitive and physical challenges enables an understanding of the various influences on perception of the pain at the central level. Figure 4 illustrates some of the cortical and sub-cortical areas 'active' during pain awareness.

How these areas connect to each other, the effect of chronic pain on these connections and the absolute activity level within an area are currently under investigation using psychosocial, psychophysical, electrostimulatory and imaging techniques.

\section{The psychosocial influences on arthritic pain}

The first recognition of the psychosocial aspects of pain is attributed to the Greek philosopher, Aristotle. ${ }^{29}$ Since the 1940 s, pain in orthopaedic conditions has been acknowledged to be influenced by an individual's personality. ${ }^{30,31}$ Initially, personality 'types' were sought to describe the patient who was felt to magnify the nociceptor input at a cortical level. More recent interest has focused on subclinical facets of patient psychology which may predispose to developing chronically painful conditions.

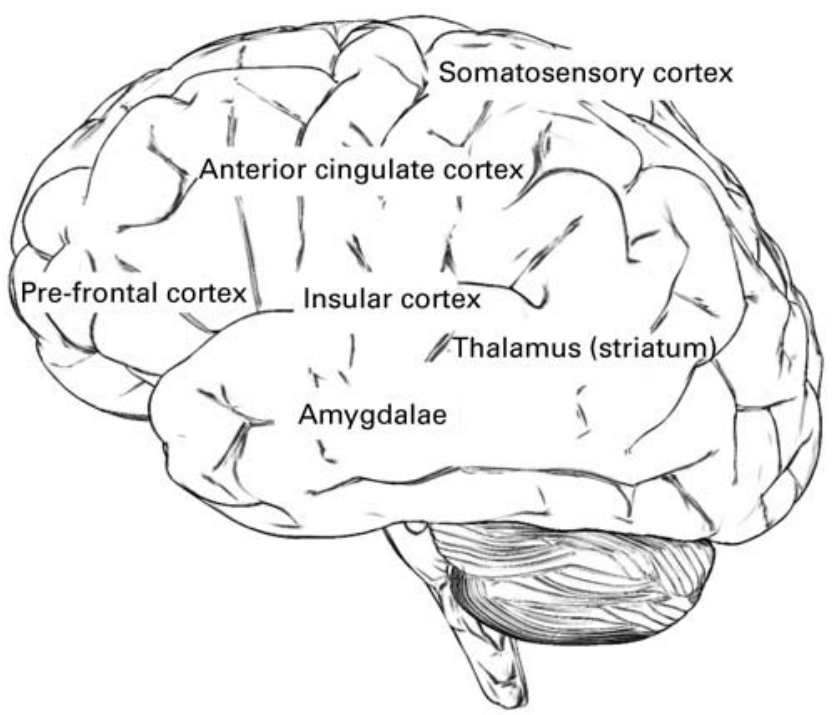

Fig. 4

Brain areas active during perception of pain. Activity in some of these areas is known to correlate to an emotional/affective situation and none is 'pain-specific'.

The demonstrable psychological traits associated with variable perception of pain include catastrophising, a situation where the patient has a tendency to focus on pain and negatively evaluate their ability to cope with it; helplessness, the belief that nothing can be done to resolve a problem, characterised by emotional, motivational and cognitive deficits; and self efficacy/coping, a belief that one can achieve specific goals through taking specific action. These, and related psychological states and their effect on pain perception, are illustrated in Figure 5.

These psychological variables have been investigated in patients experiencing painful arthritis ${ }^{32,33}$ and modulation of these traits is a target for therapeutic intervention in early osteoarthritic pain. ${ }^{34,35}$

Historically, orthopaedic training has not included an appreciation of sub-clinical psychological traits which may influence a patient's response to degenerative changes within a joint. However, it may be suggested that, either implicitly or explicitly, we already perform these assessments as part of our diagnosis and assessment for treatment, potentially exploiting them to gain benefits not directly attributable to the process of surgery itself. Arguably, this process could be further improved.

\section{The assessment of pain}

Assessing pain can be as complex or as simple as a clinician wishes. In current practice, clinicians typically make two assessments based on their consultation with a patient estimating the proportion of pain attributable to 'non-organic' factors and how much pain they believe the patient is really experiencing. These assessments, whilst not 'evidence- 

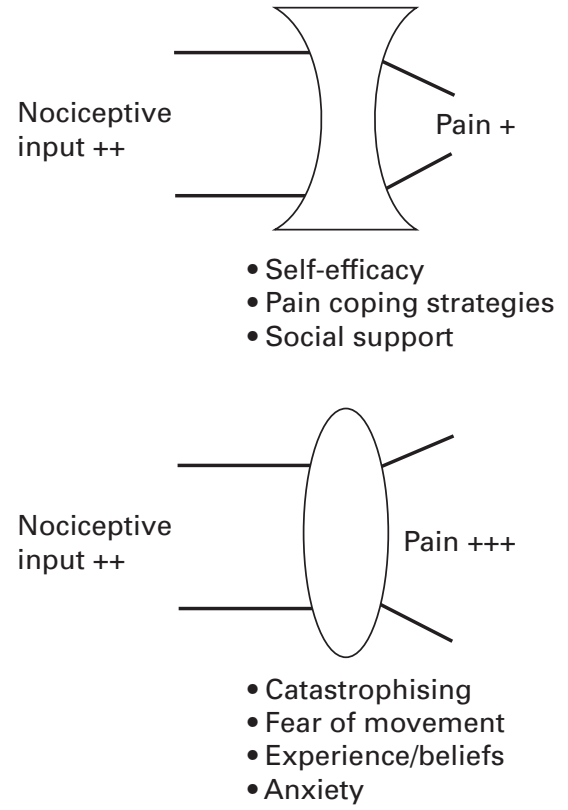

Fig. 5

Psychological states which may act to increase or reduce the perception of osteoarthritic pain.

based' are potentially robust and have historically formed a cornerstone of clinical practice. This clinical pain assessment is subtly different to pain measurement. The measurement of pain distils all contributory components of the pain pathway into the end result, the perceived pain level, whereas assessment of pain attempts to break down these components and quantifies each facet as a separate entity. For the orthopaedic surgeon, the quantification of pain measurement facilitates outcome research and may guide the provision of healthcare. On an individual basis, it provides a tool for diagnosis and treatment, and helps to predict outcome. A truly objective measure for assessing musculoskeletal pain still eludes us. ${ }^{29}$ Various options are available to the clinician and researcher including numerical scoring systems, and pain-specific, multi-dimensional disability, and arthritis specific questionnaires. During the 1980 s, there was a move to standardise the assessment of arthritic symptoms to enable comparison of research output between institutions. Composite scoring assessments of pain, function and disability have been introduced. Osteoarthritis of the hip and knee were the first to have widely-accepted assessment tools, although arthritic symptoms in other joints have now been measured in this way and validated. ${ }^{36,37}$

The Western Ontario and McMaster University Osteoarthritis Index (WOMAC), ${ }^{38-42}$ the Harris hip score ${ }^{43}$ and the Oxford Scores for the hip, ${ }^{44}$ shoulder, ${ }^{45}$ and knees, ${ }^{46}$ when combined with examination and radiological findings, are thought to be valuable in documenting the longi- tudinal progress of both treated and untreated individuals with arthritis.

When assessing pain, the extent of enquiry will clearly be context-specific. In many orthopaedic situations such as acute injury, a purely biomedical approach may be sufficient, ${ }^{47}$ although for chronic pain, a more holistic model is preferable. This latter model of pain assessment requires time, continuity of care and a high level of doctorpatient interaction. It may be difficult to achieve with the trend towards team-care, diagnostic treatment centres and non-resident surgical teams. Despite our increasing understanding of the complexity of pain and the importance of addressing the multi-faceted components of an individual's pain paradigm, there is a risk of regression into measurement rather than assessment of pain.

\section{Potential confounders to pain assessment in orthopaedics}

The influence of the placebo-effect in surgery has been highlighted in a recent randomised control trial of knee arthroscopy for OA in which a sham procedure was one of the treatment arms. ${ }^{6}$ Placebo-controlled studies illustrate the potential influence on outcomes when a patient has a positive perception of the potential physical and functional benefits to be gained from surgery. Conversely, other groups of patients may benefit socially or financially from a minimal response to operation. Meta-analysis of orthopaedic surgical outcomes has shown that the pursuit of workers' compensation and medicolegal claims significantly influences a patient's predicted response. ${ }^{48}$ There is currently no way of quantifying these influences although there have been attempts to identify patients in whom a significant non-organic component to their pain exists through clinical examination. ${ }^{49}$ It has been highlighted that these behavioural signs are not a test of credibility or 'faking' ${ }^{50}$ but act as a reminder to the clinician to consider non-organic influences on the patients presentation, and their potential response to surgery.

\section{Persistent pain after arthroplasty and the concept of the 'phantom joint'}

More than one in ten patients undergoing hip and knee replacement continue to experience pain in the operated joint. Although there is often biomechanical, pathological or iatrogenic reasons for this continuing pain, as discussed by Mandalia et al, ${ }^{51}$ there continue to be patients who feel disabling pain despite a technically successful, uncomplicated procedure.

For these patients, there may be two, potentially related, influences driving their persistent pain. First, it has been suggested that the development of chronic pain after joint replacement is influenced by genetic and psychosocial factors. It has been observed more commonly in women than men. ${ }^{8}$ It has also been shown that the expectations of the patient affect the functional outcomes and satisfaction following knee replacement ${ }^{52}$ and the presence of good 
social support for patients pre-operatively improves the pain-relieving benefit from joint replacement surgery. ${ }^{53}$ There is also growing evidence that the central nervous system may set up mechanisms which may continue to drive pain after the removal of nociceptive input, in this instance, the joint. This may be thought of as similar to the well described phenomenon of phantom limb pain after amputation for a chronically painful condition. ${ }^{54}$

In these circumstances, the chronic input from the arthritic joint, potentially influenced by the genetic and psychosocial profile of the patient, sets up 'plastic' mechanisms of sensitisation within the central nervous system. The potential effect of these alterations in pain perception may correlate to, and potentially underly, the pain seen after arthroplasty that has recently been highlighted. ${ }^{55}$ Removal of the joint may not reverse these central pathways and thus the patient continues to experience pain which appears to arise from a joint which no longer exists. Investigation of the role of central sensitisation and the development of a phantom joint is important in our understanding of this challenging cohort of patients.

\section{Orthopaedic surgeons as pain managers}

Surgeons have unique skills in the management of pain in OA. However, surgical options are not always the most appropriate as illustrated by the adage, "A good surgeon knows how to operate. A great surgeon knows when to operate". ${ }^{56}$ Avoiding surgery may be appropriate when the level of pain appears disproportionate to the disorder and/or there is evidence of catastrophising, helplessness or failure to cope. Indeed it is reported that between $15 \%$ and $30 \%$ of patients who undergo total joint replacement are dissatisfied with the outcome. ${ }^{57,58}$ The finding of sub-optimal outcomes following joint replacement has become more widely acknowledged since the application of patient related outcome measures of joint surgery such as the Oxford hip and knee scores. ${ }^{44,46}$ Studies using these measures have shown that patient dissatisfaction post-operatively is related to ongoing pain in the affected joint. ${ }^{59}$ Persistent pain, and hence dissatisfaction, following joint replacement suggests that at least a proportion of patients may have extraarticular components to their pain, which perpetuates it despite a well conducted operation.

These situations draw into question the concept of illness-disease syllogism, on which much of our practice is based. This logic has been attributed to Sydenham, who in the 1700s, described illness in terms of symptoms and signs, which in turn are symbolic of an underlying pathoanatomical disorder, the disease. ${ }^{60}$ This leads to the view that surgically removing disease or tissue will therefore remove illness. Despite the validity of this presumption in certain situations, we still manage a challenging cohort of patients who present with a history of pain but inconsistent pathology. In this small but significant group it is important to remember that we are managing pain behaviour and distress, rather than a pure nociceptor stimulus. ${ }^{61}$ Central to

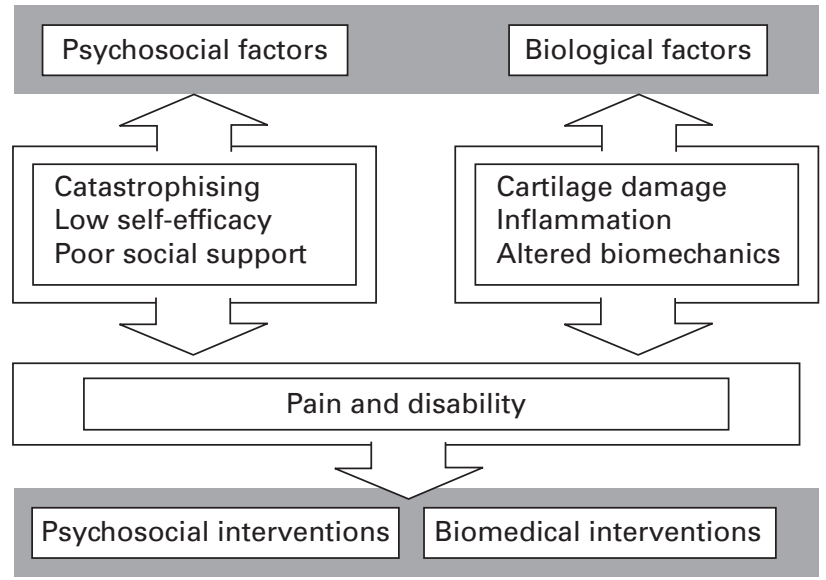

Fig. 6

The treatment options in arthritic disease based on the relative contribution of physical and psychosocial factors (adapted from Keefe et $\left.\mathrm{al}^{34}\right)$. Psychosocial approaches to managing arthritic pain include educational programmes, coping skills, training and cognitive behavioural therapy.

the management of this group of patients is an assessment of their pain, its facets and the sites which may be amenable to intervention. From this assessment a biomedical, psychosocial or combined treatment regime may offer the greatest chance of success, whilst minimising potential morbidity, mortality and disappointment (Fig. 6).

Using psychological interventions in painful OA has been found to decrease distress and reduce pain, at least in the short term. ${ }^{35}$ Such management may represent a useful adjunct in the non-surgical treatment of patients with pain and associated disability from OA, although the costeffectiveness and acceptability to both patients and clinicians has yet to be established.

\section{Treatments for osteoarthritic pain and their potential sites of action}

Table $\mathrm{I}^{62-76}$ identifies potential treatment modalities for patients presenting with pain in the knee secondary to OA and their proposed site of action along the pain pathway from nociceptor to awareness. ${ }^{62-64}$

\section{Conclusion}

It is widely regarded that radiological changes do not correlate with cartilage damage and neither radiographs nor cartilage damage correlate with the pain experienced by patients with OA. The OA model of pain exemplifies its complex nature and demands detailed knowledge of the transmission of a painful stimulus from the periphery to consciousness. The key to understanding the pain experienced by a patient with OA is to remain aware of the potential confounders for which there are no physical cues. The influence of a patient's psychological state, social situation and past experiences will all influence the pain displayed, 
Table I. Potential treatments for patients presenting with pain in the knee secondary to osteoarthritis

\begin{tabular}{|c|c|c|c|}
\hline Treatment & Proposed primary effect & $\begin{array}{l}\text { Site of action along pain } \\
\text { transmission pathway }\end{array}$ & Comments/references \\
\hline Weight loss & Mechanical & $\begin{array}{l}\text { Decreased nociceptor stimula- } \\
\text { tion }\end{array}$ & $\begin{array}{l}\text { Weight loss has more effect on disa- } \\
\text { bility than pain } 65\end{array}$ \\
\hline Physiotherapy & Mechanical stabilisation & $\begin{array}{l}\text { Decreased nociceptor stimula- } \\
\text { tion }\end{array}$ & $\begin{array}{l}\text { Insufficient data to determine opti- } \\
\text { mum exercise or frequency }\end{array}$ \\
\hline Glucosamine & $\begin{array}{l}\text { Suggested increased articular } \\
\text { cartilage synthesis } \\
\text { Possible 'anti-inflammatory } \\
\text { effect' - not via cyclo-oxygenase } \\
\text { system }\end{array}$ & $\begin{array}{l}\text { Decreased nociceptor stimula- } \\
\text { tion }\end{array}$ & $\begin{array}{l}\text { Glucosamine is a glycoprotein } \\
\text { derived from marine exoskeletons } \\
\text { or produced synthetically. }{ }^{66}\end{array}$ \\
\hline Chondroitin sulphate & $\begin{array}{l}\text { Suggested increased articular } \\
\text { cartilage synthesis }\end{array}$ & $\begin{array}{l}\text { Decreased nociceptor stimula- } \\
\text { tion }\end{array}$ & $\begin{array}{l}\text { Chondroitin is manufactured from } \\
\text { natural sources, such as shark and } \\
\text { bovine cartilage. } 66\end{array}$ \\
\hline $\begin{array}{l}\text { Transcutaneous electrical } \\
\text { nerve stimulation }\end{array}$ & $\begin{array}{l}\text { Acts by 'blocking' nociceptor } \\
\text { input to spinal cord }\end{array}$ & $\begin{array}{l}\text { Dorsal horn synapse of spinal } \\
\text { cord }\end{array}$ & $\begin{array}{l}A \beta \text { fibre input 'closes the gate' to } \\
\text { painful } A \delta \text { and } C \text { fibre } \\
\text { transmission }^{67}\end{array}$ \\
\hline \multirow[t]{3}{*}{ Acupuncture } & Activation of a gate control system & $\begin{array}{l}\text { Dorsal horn synapse of spinal } \\
\text { cord and supraspinal nuclei }\end{array}$ & $\begin{array}{l}\text { Western view of mechanism. Origi- } \\
\text { nal view is interaction with } \mathrm{Qi} \\
\text { energy flow }{ }^{62}\end{array}$ \\
\hline & $\begin{array}{l}\text { Stimulation of the release of } \\
\text { neurochemicals in the central } \\
\text { nervous system }\end{array}$ & & \\
\hline & Placebo & & \\
\hline Psychological therapy & $\begin{array}{l}\text { Alters supraspinal modulation } \\
\text { of incoming nociceptive input }\end{array}$ & Supraspinal nuclei & $34,68,69$ \\
\hline Paracetomol & $\begin{array}{l}\text { Selective inhibition of the enzyme } \\
\text { COX-3 in the brain and spinal cord } \\
\text { Paracetomol is converted to } \\
\mathrm{N} \text {-arachidonoylphenolamine, a } \\
\text { compound already known as an } \\
\text { endogenous cannabinoid }\end{array}$ & $\begin{array}{l}\text { Spinal cord synapse and } \\
\text { supra-spinal nuclei }\end{array}$ & 70,71 \\
\hline $\begin{array}{l}\text { Non-steroidal anti- } \\
\text { inflammatory drugs }\end{array}$ & Cyclo-oxygenase-2 inhibitors & $\begin{array}{l}\text { Decrease peripheral sensitisa- } \\
\text { tion of nociceptors by reducing } \\
\text { localised inflammatory media- } \\
\text { tors }\end{array}$ & 63 \\
\hline Opiates & $\begin{array}{l}\text { Agonists/partial agonists of the } \\
\text { endogenous opiate system }\end{array}$ & $\begin{array}{l}\text { Spinal cord synapse and supra- } \\
\text { spinal nuclei }\end{array}$ & 64 \\
\hline Intra-articular steroid injection & $\begin{array}{l}\text { Decrease sensitisation of joint } \\
\text { nociceptors by decreasing local } \\
\text { inflammatory mediators }\end{array}$ & $\begin{array}{l}\text { Decreased nociceptor stimula- } \\
\text { tion }\end{array}$ & 72,73 \\
\hline \multirow{2}{*}{$\begin{array}{l}\text { Synthetic synovial fluid } \\
\text { replacement }\end{array}$} & \multirow{2}{*}{$\begin{array}{l}\text { Temporary restoration of lubricating } \\
\text { and shock-absorbing effects of } \\
\text { synovial fluid }\end{array}$} & \multirow{2}{*}{$\begin{array}{l}\text { Decreased nociceptor stimula- } \\
\text { tion }\end{array}$} & 74 \\
\hline & & & $\begin{array}{l}\text { Whether hyaluronan ameliorates or } \\
\text { modifies disease progression has } \\
\text { not been determined and remains } \\
\text { the subject of speculation }\end{array}$ \\
\hline \multirow{4}{*}{$\begin{array}{l}\text { Arthroscopic washout/ } \\
\text { debridement }\end{array}$} & 1) Removal of particulate debris & $(1,2$ and 3$)$ & \multirow[t]{4}{*}{75} \\
\hline & $\begin{array}{l}\text { 2) Removal of degenerative } \\
\text { enzymes and inflammatory } \\
\text { mediators }\end{array}$ & $\begin{array}{l}\text { Decreased nociceptor stimula- } \\
\text { tion }\end{array}$ & \\
\hline & 3) Reduced distension of capsule & & \\
\hline & 4) Placebo & 4) supraspinal nuclei & \\
\hline Arthroplasty & $\begin{array}{l}\text { Removes degenerate joint and } \\
\text { associated neural structures }\end{array}$ & $\begin{array}{l}\text { Decreased nociceptor stimula- } \\
\text { tion } \\
\text { Decreased central sensitisation }\end{array}$ & $\begin{array}{l}\text { Arthroplasty decreases pain both } \\
\text { within the affected joint and at } \\
\text { distant site }\end{array}$ \\
\hline
\end{tabular}


and identifying the importance of these factors requires a detailed assessment of the patient and their pain. Sometimes it may be appropriate to utilise validated questionnaires to assist in this process. Using this approach may increase the percentage of people who experience significant improvements in pain and function either by identifying them as potentially benefiting from non-surgical options or by suggesting more involved neo-adjuvant treatment in the form of increased support from the medical team or more formal psychological assessment.

If patient management based on surgical syllogism alone is adopted, then the specialty risks demotion to the role of technician with encompassing patient care being the realm of physicians and non-medical specialists who prescribe surgery as part of their treatment plan.

There is little doubt that some patients 'feel' pain more than others. As we move towards the ability to quantitatively assess an individual's sensitivity to pain there is the potential to predict the pain-relieving effect of surgical intervention, enabling us both to rationalise our treatments and to provide more fully informed consent. In order to understand these patients fully, we need to investigate the validity of the 'phantom joint' concept and its influence on the population whom we treat with ongoing pain after arthroplasty. Ultimately, this may help us reduce the proportion of patients who continue to feel pain after joint replacement for no apparent technical or pathological reasons. Even with the potential development of image-based quantification of pain we shall continue to rely on clinical assessment, acumen and validated assessment tools in order to understand the pain experienced by a patient with OA. An appreciation of the multi-dimensional nature of the perception of pain will enable the surgeon to apply a more robust pre-operative assessment of a patient's suitability for surgery.

\section{References}

1. Brooks P. Issues with chronic musculoskeletal pain. Rheumatology (Oxford)2005;44:831-3. 2. Hadler NM. Knee pain is the malady: not osteoarthritis. Ann Intern Med 1992;116:598-9.

3. Harkness EF, Macfarlane GJ, Silman AJ, McBeth J. Is musculoskeletal pain more common now than 40 years ago?: two population-based cross-sectional studies. Rheumatology (Oxford) 2005;44:890-5.

4. DeLeo JA. Basic science of pain. J Bone Joint Surg [Am]2006;88-A(Suppl 2):58-62.

5. Benini A, DeLeo JA. René Descartes' physiology of pain. Spine 1999;24:2115-19.

6. Moseley JB, O'Malley K, Petersen NH, et al. A controlled trial of arthroscopic surgery for osteoarthritis of the knee. N Engl J Med 2002;347:81-8.

7. Moseley JB Jr, Wray NP, Kuykendall D, Willis K, Landon G. Arthroscopic treatment of osteoarthritis of the knee: a prospective, randomized, placebo-controlled trial: results of a pilot study. Am J Sports Med 1996;24:28-34.

8. Nikolajsen L, Brandsborg B, Lucht U, Jensen TS, Kehlet H. Chronic pain following total hip arthroplasty: a nationwide questionnaire study. Acta Anaesthesiol Scand 2006;50:495-500

9. Elson DW, Brenkel J. A conservative approach is feasible in unexplained pain after knee replacement: a selected cohort study. J Bone Joint Surg [Br]2007;89-B:1042-5.

10. Kellgren JH, Lawrence JS. Rheumatism in miners. II: X-ray study. Br J Ind Med 1952:9:197-207.

11. Dieppe PA, Lohmander LS. Pathogenesis and management of pain in osteoarthritis. Lancet2005;365:965-73.

12. Summers MN, Haley WE, Reveille JD, Alarcón GS. Radiographic assessment and psychologic variables as predictors of pain and functional impairment in osteoarthritis of the knee or hip. Arthritis Rheum 1988;31:204-9.
13. van Baar ME, Dekker J, Lemmens JA, Oostendorp RA, Bijlsma JW. Pain and disability in patients with osteoarthritis of hip or knee: the relationship with articular, kinesiological, and psychological characteristics. J Rheumato/ 1998;25:125-33.

14. Cobb S, Merchant WR, Rubin T. The relation of symptoms to osteoarthritis. J Chronic Dis 1957;5:197-204.

15. Dekker J, Boot B, Van der Woude LH, Bijlsma JW. Pain and disability in osteoarthritis: a review of biobehavioral mechanisms. J Behav Med 1992;15:189-214.

16. Hadler NM. Osteoarthritis as a public health problem. Clin Rheum Dis 1985;11:175-85.

17. Fillingim RB. Individual differences in pain responses. Curr Rheumatol Rep 2005;7:342-7.

18. Ordeberg G. Characterization of joint pain in human OA. Novartis Found Symp 2004;260:105-15.

19. Kellgren JH, Samuel EP. The sensitivity and innervation of the articular capsule. J Bone Joint Surg [Br] 1950;32-B:84-92.

20. Heppelmann B, Messlinger K, Schaible HG, Schmidt RF. Nociception and pain. Curr Opin Neurobiol 1991;1:192-7.

21. Messlinger K. What is a nociceptor? Der Anaesthetist 1997;46:142-53 (in German).

22. Saxler G, Löer F, Skumavc M, Pförtner J, Hanesch U. Localization of SP- and CGRPimmunopositive nerve fibers in the hip joint of patients with painful osteoarthritis and of patients with painless failed total hip arthroplasties. Eur J Pain 2007;11:67-74.

23. Freeman MA, Wyke B. The innervation of the knee joint: an anatomical and histological study in the cat. J Anat 1967;101:505-32.

24. Guilbaud G, Iggo A, Tegnér R. Sensory receptors in ankle joint capsules of normal and arthritic rats. Exp Brain Res 1985;58:29-40.

25. Zimmerman M. Pain mechanisms and mediators in osteoarthritis. Semin Arthritis Rheum 1989;18(4 Suppl 2):22-9.

26. Tracey I. Nociceptive processing in the human brain. Curr Opin Neurobio/2005;15:478-87.

27. Apkarian AV, Bushnell MC, Treede RD, Zubieta JK. Human brain mechanisms of pain perception and regulation in health and disease. Eur J Pain 2005;9:463-84.

28. Peyron R, Laurent B, García-Larrea L. Functional imaging of brain responses to pain: a review and meta-analysis (2000). Neurophysiol Clin 2000;30:263-88.

29. Bird HA, Dixon JS. The measurement of pain. Baillieres Clin Rheumato/ 1987;1:71-89.

30. Luck J. Psychosomotic problems in military orthopaedic surgery. J Bone Joint Surg 1946;28:213-28.

31. Lihn H, Menninger K, Mayman M. Personality factors in osteoarthritis. Res Publ Assoc Res Nerv Ment Dis 1949;29:744-9.

32. Lunghi ME, Miller PM, McQuillan WM. Psycho-social factors in osteoarthritis of the hip. J Psychosom Res 1978;22:57-63.

33. Buckelew SP, Parker JC. Coping with arthritis pain: a review of the literature. Arthritis Care Res 1989;2:136-45.

34. Backman CL. Arthritis and pain: psychosocial aspects in the management of arthritis pain. Arthritis Res Ther 2006;8:221.

35. Keefe FJ, Smith SJ, Buffington AL, et al. Recent advances and future directions in the biopsychosocial assessment and treatment of arthritis. I Consult Clin Psychol 2002; $70: 640-55$

36. Leak AM, Cooper J, Dyer S, et al. The Northwick Park Neck Pain questionnaire, devised to measure neck pain and disability. Br J Rheumatol 1994;33:469-74.

37. Fairbank JC, Couper J, Davies JB, O'Brien JP. The Oswestry low back pain disability questionnaire. Physiotherapy 1980;66:271-3.

38. Bellamy N. Pain assessment in osteoarthritis: experience with the WOMAC osteoarthritis index. Semin Arthritis Rheum 1989;18(4 Suppl 2):14-17.

39. Bellamy N. WOMAC: a 20-year experiential review of a patient-centered self-reported health status questionnaire. J Rheumatol 2002;29:2473-6.

40. Bellamy N. The WOMAC knee and hip osteoarthritis indices: development, validation, globalization and influence on the development of the AUSCAN Hand Osteoarthritis Indices. Clin Exp Rheumato/ 2005;23(5 Suppl 39):148-53.

41. Bellamy N, Buchanan WW, Goldsmith CH, Campbell J, Stitt LW. Validation study of WOMAC: a health status instrument for measuring clinically important patient relevant outcomes to antirheumatic drug therapy in patients with osteoarthritis of the hip or knee. J Rheumato/ 1988;15:1833-40.

42. Yang KG, Raijmakers NJ, Verbout AJ, Dhert WJ, Saris DB. Validation of the shortform WOMAC function scale for the evaluation of osteoarthritis of the knee. J Bone Joint Surg [Br] 2007;89-B:50-6.

43. Harris WH. Traumatic arthritis of the hip after dislocation and acetabular fractures: treatment by mold arthroplasty: an end-result study using a new method of result evaluation. J Bone Joint Surg [Am] 1969;51-A:737-55.

44. Dawson J, Fitzpatrick R, Carr A, Murray D. Questionnaire on the perceptions of patients about total hip replacement. J Bone Joint Surg [Br] 1996;78-B:185-90.

45. Dawson J, Fitzpatrick R, Carr A. Questionnaire on the perceptions of patients about shoulder surgery. J Bone Joint Surg [Br] 1996;78-B:593-600.

46. Dawson J, Fitzpatrick R, Murray D, Carr A. Questionnaire on the perceptions of patients about total knee replacement. J Bone Joint Surg [Br] 1998;80-B:63-9. 
47. Vlaeyen JW, Kole-Snijders AM, Boeren RG, van Eek H. Fear of movement/ (re)injury in chronic low back pain and its relation to behavioral performance. Pain 1995:62:363-72.

48. Harris I, Mulford J, Solomon M, van Gelder JM, Yang J. Association between compensation status and outcome after surgery: a meta-analysis. JAMA 2005;293:1644-52

49. Waddell G, McCulloch JA, Kummel E, Venner RM. Nonorganic physical signs in low-back pain. Spine 1980;5:117-25.

50. Main CJ, Waddell G. Behavioural responses to examination: a reappraisal of the interpretation of "nonorganic signs". Spine 1998;23:2367-71.

51. Mandalia V, Eyers K, Schranz P, Toms A. Evaluation of patients with painful tota knee replacement. J Bone Joint Surg [Br]2008;90-B:265-71.

52. Noble PC, Conditt MA, Cook KF, Mathis KB. The John Insall Award: patien expectations affect satisfaction with total knee arthroplasty. Clin Orthop 2006;452:35-43.

53. Escobar A, Quintana JM, Bilbao A, et al. Effect of patient characteristics on reported outcomes after total knee replacement. Rheumatology (Oxford) 2007:46:112-19.

54. Melzack R. Phantom limb pain: implications for treatment of pathologic pain. Anes thesiology 1971;35:409-19.

55. Lundblad H, Kreicbergs A, Jannsan KA. Prediction of persistant pain after total knee replacement for osteoarthritis. J Bone Joint Surg [Br] 2008;90-B:166-71.

56. Godlee F. The fight for primary care. BMJ 2007;335: doi:10.1136/ bmj.39336.570116.47

57. Jones CA, Beaupre LA, Johnson DW, Suarez-Almazor ME. Total joint arthroplasties: current concepts of patient outcomes after surgery. Rheum Dis Clin North Am 2007;33:71-86.

58. No authors listed. National Joint Registry for England and Wales. Summary repor (2nd Annual Report). http://www.njrcentre.org.uk 2005 (date last accessed 11 January 2008).

59. Baker PN, van der Meulen, Lewsey J, et al. The role of pain and function in determining patient satisfaction after total knee replacement: data from the National Joint Registry for England and Wales. J Bone Joint Surg [Br]2007;89-B:893-900.
60. Hadler NM. Why does the patient with osteoarthritis hurt? In: Brandt KD, Doherty M, Lohmander LS, eds. Osteoarthritis. Second ed. Oxford: Oxford University Press, 2003.

61. Main CJ, Watson PJ. Psychological aspects of pain. Man Ther 1999;4:203-15.

62. Berman B. A 60-year-old woman considering acupuncture for knee pain. JAMA 2007;297:1697-707.

63. Felson DT. Clinical practice: osteoarthritis of the knee. N Eng/ J Med 2006;354:8418

64. Glass GG. Osteoarthritis. Dis Mon 2006;52:343-62.

65. Christensen R, Bartels EM, Astrup A, Briddal H. Effect of weight reduction in obese patients diagnosed with knee osteoarthritis: a systematic review and metaanalysis. Ann Rheum Dis 2007;66:433-9.

66. Wolinsky I, Driskell JA, eds. Nutritional ergogenic acids. Florida: CRC Press, 2004.

67. Osiri M, Welch V, Brosseau L, et al. Transcutaneous electrical nerve stimulation for knee osteoarthritis. Cochrane Database Syst Rev 2000;CD002823.

68. Keefe FJ, Abernethy AP, Campbell CL. Psychological approaches to understanding and treating disease-related pain. Annu Rev Psychol 2005;56:601-30.

69. Price DD. Psychological and neural mechanisms of the affective dimension of pain. Science 2000;288:1769-72.

70. Flower RJ, Vane JR. Inhibition of prostaglandin synthetase in brain explains the anti-pyretic activity of paracetomol (4-acetamidophenol). Nature 1972;240:410-11.

71. Bertolini A, Ferrari A, Ottani A, et al. Paracetomol: new vistas of an old drug. CNS Drug Rev 2006;12:250-75.

72. Creamer P. Intra-articular corticosteroid injections in osteoarthritis: do they work and if so, how? Ann Rheum Dis 1997;56:634-6.

73. Bellamy N, Campbell J, Robinson V, et al. Intraarticular corticosteroid for treatment of osteoarthritis of the knee. Cochrane Database Syst Rev 2006:CD005328.

74. Bellamy N, Campbell J, Robinson V. Viscosupplementation for the treatment of osteoarthritis of the knee. Cochrane Database Syst Rev 2006:CD005321.

75. Brandley JD. Iririgation joint. In: Brandt KD, Doherty M, Lohmander LS, eds. Osteoarthritis. Second ed. Oxford: Oxford University Press, 2003

76. Bradley LA, Kersh BC, DeBerry JJ, et al. Lesson from fibromyalgia: abnormal pain sensitivity in knee osteoarthritis. Novartis Found Symp 2004;260:258-70. 